\title{
Blepharipoda spinosa (H. Milne Edwards \& Lucas, 1841) and Lepidopa chilensis Lenz, 1902 (Crustacea: Hippoidea) larvae on a north-central zone of Chile
}

\author{
Armando Mujica $^{1}(\mathbb{D})$, Francisca González-Salas ${ }^{1} \mathbb{D}$ \& María Luisa Nava ${ }^{1}$ \\ ${ }^{1}$ Departamento de Acuicultura, Facultad de Ciencias del Mar, Universidad Católica del Norte \\ Coquimbo, Chile \\ Corresponding author: Armando Mujica (amujica@ucn.cl)
}

\begin{abstract}
The larvae of Blepharipoda spinosa and Lepidopa chilensis were collected from Chile's northcentral coast (Paposo $25.0^{\circ} \mathrm{S}$ and Oscuro Port $31.5^{\circ} \mathrm{S}$ ) in each February of 2013-2017. Larvae were separated by their development stage. Their abundance, occurrence, and distribution concerning its proximity to the coast were analyzed. Larval abundance and frequency of occurrence were low in both species. Zoea I dominated the highest concentrations detected in coastal stations and near the study area's longest sandy beaches. Interannual variation of larvae was seen in the abundance and composition by development stages. The highest abundance of B. spinosa larvae was found in February 2016, while L. chilensis larvae had the highest abundance in February 2014. Their presence and development stages in the wide sampling area provide information on both species' distribution and reproductive activity.
\end{abstract}

Keywords: Blepharipoda spinosa; Lepidopa chilensis; larval stages; distribution; north-central Chile

Boyko (2002) separated in his taxonomic revision of the Hippoidea superfamily the species of the Albuneidae family, generating a new family (Blepharipodidae). According to this revision, Blepharipoda spinosa $(\mathrm{H}$. Milne Edwards \& Lucas, 1841) and Lepidopa chilensis Lenz, 1902 have remained in the families Blepharipodidae and Albuneidae, respectively. The original name of Blepharipoda spinimana, which has been used for the species described off the coast of continental Chile, has become synonymy with Blepharipoda spinosa (WoRMS 2020).

Retamal (2000) pointed out that B. spinosa and $L$. chilensis are unique species in their respective genera along the Chilean coast. Both species inhabit the shallow sandy intertidal zone and have a wide geographical distribution along the continental coast of Chile, occurring between Iquique and Valdivia (18$42^{\circ}$ S) (Retamal \& Moyano 2010).

No published information on the biology (fertility, size structure, sexual proportion, reproductive season) of B. spinosa and L. chilensis is available. Reports of these species are scarce, both for the coasts of Peru and
Chile, and they occur typically in low concentrations (Jaramillo et al. 2000, Boyko 2002, Laudien et al. 2007, Moscoso 2012). The presence of larvae of both species has only been reported in plankton samples from the Chilean coast (Mujica 2006, Yannicelli et al. 2006a,b, Rivera et al. 2019). Larvae of $B$. spinosa have also been collected in channels and fjords of the Aysen Region (43.5-45 $\left.{ }^{\circ} \mathrm{S}\right)$, which is south of the reported distribution of the adults (Mujica 2003, 2007, 2008, Balbontín et al. 2009).

B. spinosa larvae were described by Knight (1968) from plankton specimens. This author compared the larvae with $B$. occidentalis and described five zoeal stages for B. occidentalis and four for B. spinosa. On the other hand, Sánchez \& Aguilar (1975) described the larval development of five zoeal stages for $L$. chilensis, obtained under laboratory conditions.

This study provides information on the distribution and abundance of larval stages of $B$. spinosa and $L$. chilensis in Chile's north-central coastal zone (25.0$31.5^{\circ} \mathrm{S}$ ), and the obtained results allow inferring about the geographic distribution of the adults.

Corresponding editor: Ingo Wehrtmann 


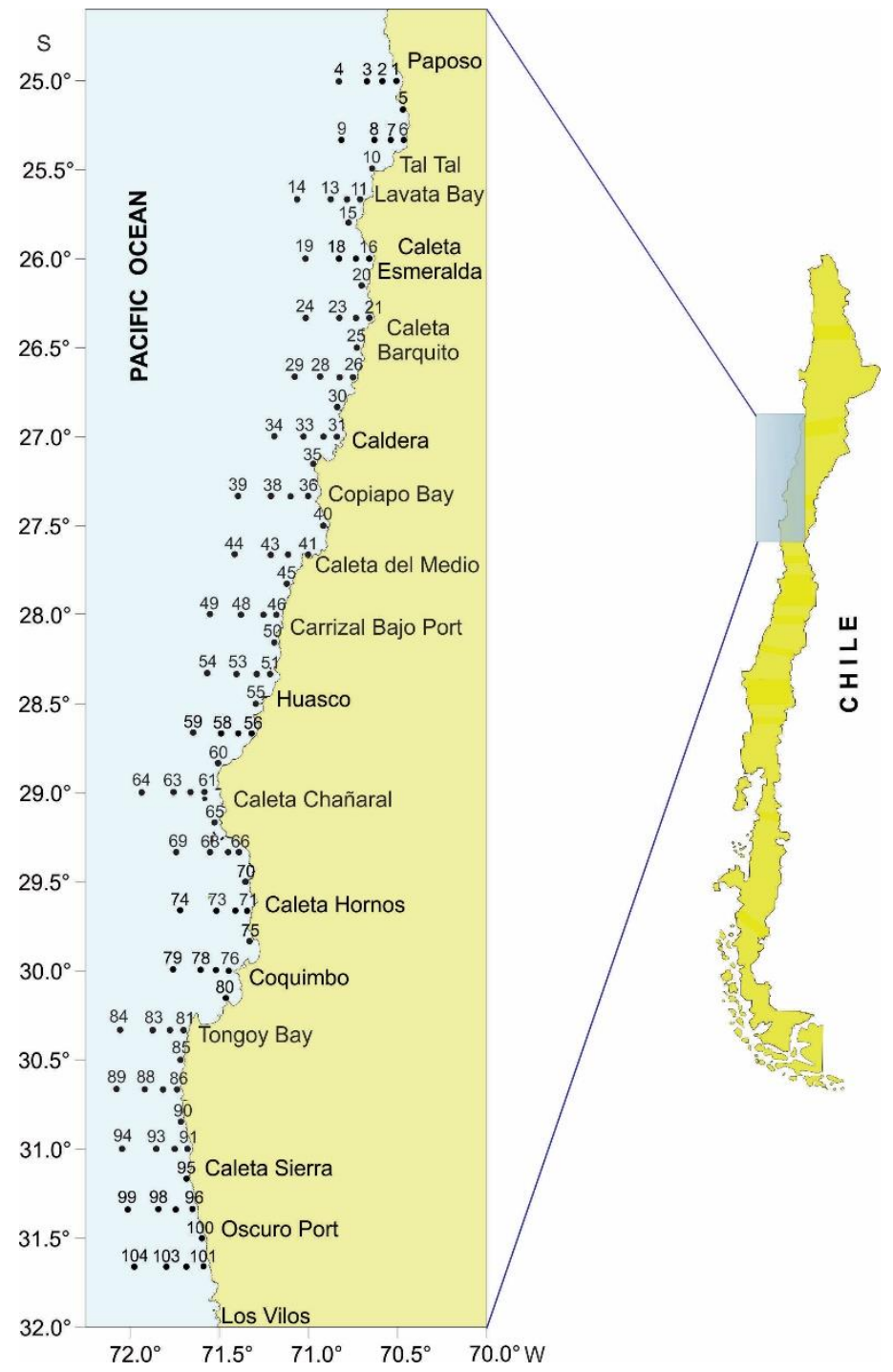

Figure 1. Location of zooplankton sampling stations in north-central Chile (February 2013-2017).

Each February in 2013-2017, zooplankton samples were taken on board of RV Abate Molina at 80 oceanographic stations, distributed in 20 transects perpendicular to the coast, between Paposo and Oscuro Port (Fig. 1), with stations at 1, 5, 10 and $20 \mathrm{~nm}$ from the coast and 20 stations at $1 \mathrm{~nm}$ from the coast between each transect.

Zooplankton samples were taken using $59 \mathrm{~cm}$ diameter Bongo nets with $300 \mu \mathrm{m}$ mesh opening and equipped with flow meters; collection took place between $70 \mathrm{~m}$ depth and the surface or $10 \mathrm{~m}$ above the bottom when the site's depth was less. Samples were preserved in a $5 \%$ formalin solution in seawater. Larvae of B. spinosa and L. chilensis were separated and quantified (larvae $100 \mathrm{~m}^{-3}$ ). The development stages of both species were identified according to the descrip- tions made by Knight (1968) and Sánchez \& Aguilar (1975), respectively.

In the time series analyzed, $B$. spinosa larvae were not very abundant (16-231 larvae $\left.100 \mathrm{~m}^{-3}\right)$, with a low frequency of occurrence (1.0 to $8.7 \%$ of all stations) and preferential with a near-coastal distribution $(1 \mathrm{~nm}$ from the coast). Larvae of both species were found only at three stations located at $5 \mathrm{~nm}$ from the coast and one at $20 \mathrm{~nm}$. The highest total concentration of larvae was found in February 2013 (134 larvae $100 \mathrm{~m}^{-3}$ ) and 2016 (231 larvae $100 \mathrm{~m}^{-3}$ ), mainly in the sector called "Coquimbo Bay Systems" (CBS) (st. 65-77), between Caleta Chañaral $\left(29^{\circ} 10^{\prime} \mathrm{S}\right)$ and Tongoy Bay $\left(30^{\circ} 10^{\prime} \mathrm{S}\right)$. More than $83 \%$ of the total larvae were captured in this sector in February 2013, 2016, and 2017 (Table 1). 
Table 1. Distribution and abundance of Blepharipoda spinosa larval development stages in sampling stations (February 2013-2017). Stations $1 \mathrm{~nm}$ from the coast. $₫$ Stations $5 \mathrm{~nm}$ from the coast. $₫$ Stations $20 \mathrm{~nm}$ from the coast. FO: frequency of total annual occurrence.

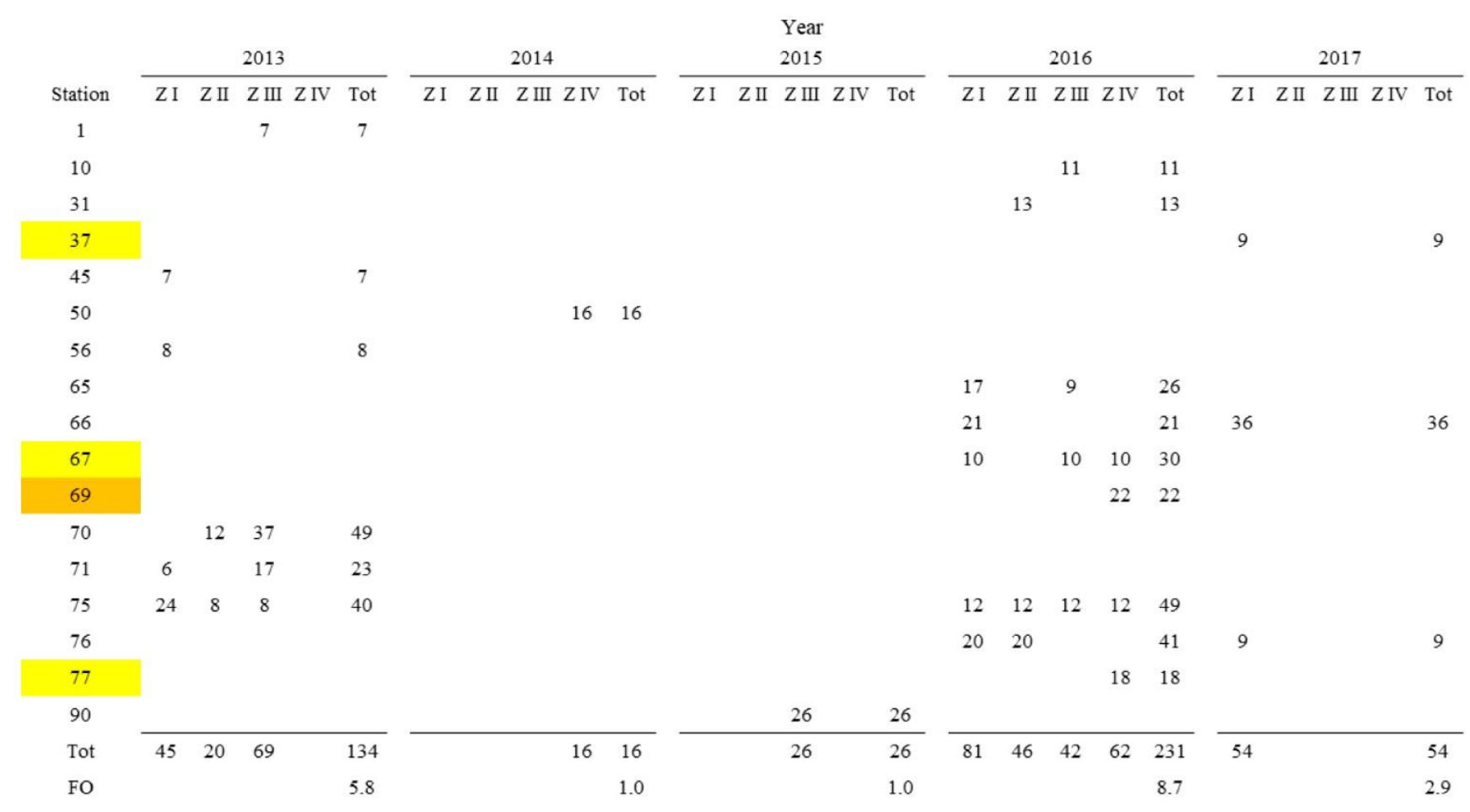

In February 2013, larvae of the first three zoeal stages were collected only at stations located $1 \mathrm{~nm}$ from the coast and mainly in the CBS. While in February 2014 and 2015, larvae of B. spinosa were captured only at one station, with low concentrations of advanced stages (st. 50: 16 Zoea III $100 \mathrm{~m}^{-3}$ and st. 90: 26 Zoea IV $100 \mathrm{~m}^{-3}$, respectively).

All larvae development stages were collected in February 2016, 35\% in the CBS region and mostly at 1 $\mathrm{nm}$ from the coast. The vast majority of Zoea I and II was encountered at coastal stations, while specimens of Zoea IV were caught mainly 5 and $20 \mathrm{~nm}$ from the coast (Table 1). In February 2017, larvae (exclusively Zoea I) were collected only at three stations, two of which were located $1 \mathrm{~nm}$ from the coast and one $5 \mathrm{~nm}$.

The highest occurrence of B. spinosa larvae was observed when the El Niño event declined (February 2016, Table 1), which took place during 2015 and is considered one of the most intense in decades (NOAA 2020). In general, the highest larval abundances in the CBS (Table 1) were associated with the longest sandy beaches in the sampling area.

The distribution and larval abundance in the summer of consecutive years provide information on the reproductive season and the geographic distribution of the corresponding adults. Currently, our knowledge on adult populations is based on reports of collections from sandy beaches without information on their abundance (Jaramillo et al. 2000, 2008, Retamal 2000, Laudien et al. 2007). On the other hand, information on larvae is restricted to samplings made in summer at different latitudes within the distribution indicated for adults (Knight 1968, Yannicelli et al. 2006a,b) and even south of it (Mujica 2003, 2006, 2008). Therefore, the results provided here include information that should promote studies related to the dynamics of adult populations in places close to the collection of larvae, especially those areas with a high abundance of early larval stages.

Rivera et al. (2019) found larvae of B. spinosa near the coast at different times of the year in northern Chile, suggesting a continuous reproductive activity of the species. The second peak of larval abundance coincides with when the present study was carried out (summer).

In the present study, larvae of $L$. chilensis larvae were not very abundant $\left(27-233\right.$ larvae $\left.100 \mathrm{~m}^{-3}\right)$ and with a low frequency of occurrence (1.9-4.8\% of stations in the time series). They showed a coastal distribution (1 and 
Table 2. Distribution and abundance of larval development stages of Lepidopa chilensis in sampling stations (February 2013-2017). Stations at $1 \mathrm{~nm}$ off the coast. $₫$ Stations at $5 \mathrm{~nm}$ off the coast. FO: frequency of total annual occurrence.

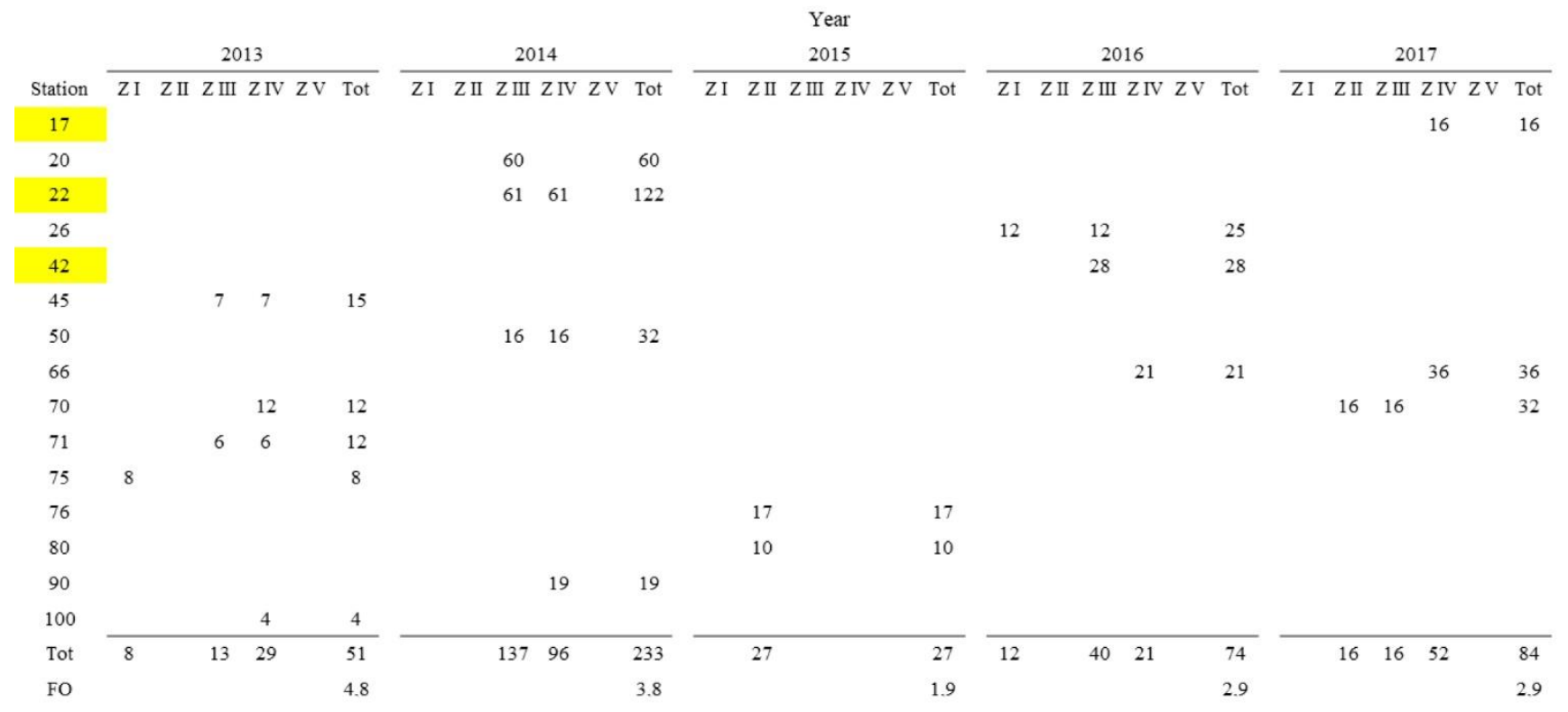

$5 \mathrm{~nm}$ from the coast). The highest abundances were found in February 2014 (50\% of the total), mostly at 5 nm off Caleta Barquito (Table 2, Fig. 1).

In the remaining sampling periods, the abundance of $L$. chilensis larvae was low and restricted to a few stations (Table 2). Zoea III and IV larvae were predominant in the analyzed time series, except for February 2015, when only Zoea II larvae were collected. Zoea I larvae were captured exclusively in February 2016, and Zoea V larvae were not present in any analyzed samples (Table 2). The predominance of advanced larval stages indicates that the surveys were carried out after spawning. Sánchez \& Aguilar (1975) pointed out that Zoea III and IV larvae occur, under laboratory conditions, 10.8 and 19.4 days after hatching. Therefore, the duration of the first four zoeal stages of $L$. chilensis in the plankton is probably 10 to 20 days, a period where advective processes may have transported them away from the spawning site.

The predominance of early larvae of both species at stations near the coast and especially in the CBS is associated with extensive sandy beaches in the study area. In contrast, the distribution and abundance of the advanced larval stages might result from spawning in summer on the beaches. The advective processes generated by the Chile-Peru Current (Escribano et al. 2002) probably move the zooplankton in a northern direction.

Acuña et al. (1989) pointed out that the upwelling area in front of Fray Jorge National Park $\left(31^{\circ} \mathrm{S}\right)$ influences the entire CBS, including islands near Punta Choros $\left(29^{\circ} 25^{\prime} \mathrm{S}\right)$ allowing the confluence of waters from the south and west, which generates upwelling foci (Acuña et al. 2007). Some authors (Flores \& Mujica 2009, Mujica et al. 2014) suggested that a larval retention place is in the northern part of the CBS, where the highest larval concentrations of other species were found. Probably a consequence of the zooplankton drift produced by the Humboldt Current interaction, flowing from south to north (Escribano et al. 2002) and action of two turns caused by geostrophic circulation and the diurnal tides component, allowing waters coming from Tongoy Bay to reach the bays north of it (Acuña et al. 1989). According to Moraga et al. (1994), this seasonal oceanographic effect allows two surface flows to the north: one coastal and the other one from the coast that reaches up to $50 \mathrm{~m}$, separated by a smaller flow with a southern direction, reaching about 100 to $200 \mathrm{~m}$ depth. Therefore, it is assumed that the planktonic components located at different depths and distances from the coast would have different displacements, which would explain the drift and retention of the larvae in the area (Flores \& Mujica 2009).

The presence of $B$. spinosa larvae in an advanced stage of development (Zoea IV) up to $20 \mathrm{~nm}$ off the northern coast of Caleta Hornos may be related to the time they remain in the plankton and the advective processes that move them away from the hatching places.

\section{ACKNOWLEDGMENTS}

This study was funded by the projects "Hydroacoustic evaluation of anchovy recruitment between the III and 
IV Regions", awarded by the Fondo de Investigación Pesquera y de Acuicultura (FIPA). The authors also thank the support provided by the Instituto de Fomento Pesquero (IFOP) that, in partnership with Universidad Católica del Norte, obtained the information used as a starting point for the present study. Special thanks go to the crew of the IFOP research vessel R/V Abate Molina and the personnel who aided in sample collection. Florencia Arceu collaborated with the identification and analysis of the larvae, which is greatly appreciated. Finally, thanks go to José Iván Sepúlveda for the translation and critical review of the manuscript.

\section{REFERENCES}

Acuña, E., Moraga, J. \& Uribe, E. 1989. La zona de Coquimbo: un sistema nerítico de surgencia de altaproductividad. In: Jordán, R., Kelly, R., Mora, O., De Vildoso, A. \& Henríquez, N. (Eds.). Memorias del Simposio Internacional de los Recursos Vivos y las Pesquerías en el Pacífico Sudeste, Santiago, Chile: Comité Permanente Pacífico Sur, pp. 145-157.

Acuña, E., Andrade, M., Cubillos, L., Arancibia, H., Moraga, J., Mujica, A., et al. 2007. Determinación de zonas y épocas de reclutamiento de camarón nailon, langostino amarillo y langostino colorado en las regiones III y IV. Informe Final, Proyecto FIP N'2004-45.

Balbontín, F., Campos, B., Mujica, A. \& SaavedraNievas, J. 2009. Distribución de larvas de algunos invertebrados y huevos de peces en relación con factores físicos en fiordos patagónicos. Ciencia y Tecnología del Mar, 32: 49-70.

Boyko, C.B. 2002. A worldwide revision of the recent and fossil sand crabs of the Albuneidae Stimpson and Blepharipodidae, new family (Crustacea: Decapoda: Anomura: Hippoidea). Bulletin of the American Museum of Natural History, 272: 1-396.

Escribano, R., Marín, V., Hidalgo, P. \& Olivares, G. 2002. Physical-biological interactions in the pelagic ecosystem of the nearshore zone of the northern Humboldt Current System. In: Castilla, J.C. \& Larger, J.L. (Eds.). The oceanography and ecology of the nearshore and bays in Chile. Ediciones Universidad Católica de Chile, Santiago, pp. 145-175.

Flores, E. \& Mujica, A. 2009. Distribución y abundancia de larvas Emerita analoga (Stimpson 1857) (Decapoda, Anomura) en la zona de Coquimbo y Caldera, Chile. Gayana, 73: 211-221.

Jaramillo, E., Dugan, J. \& Contreras, H. 2000. Abundance, tidal movement, population structure, and burrowing rate of Emerita analoga (Anomura, Hippidae) at a dissipative and reflexive sandy beach in south-central Chile. Marine Ecology, 21: 113-127.
Jaramillo, E., Cifuentes, S., Duarte, C. \& Contreras, H. 2008. Relationships between bioturbation by Tylos spinulosus (Crustacea, Isopoda) and its distribution on sandy beaches of north-central Chile. Marine Ecology, 29: 37-42.

Knight, M. 1968. The larval development of Blepharipoda occidentalis Randall and B. spinimana (Philippi) (Decapoda, Albuneidae). Proceedings of the California Academy of Sciences, 35: 337-370.

Laudien, J., Rojo, M., Oliva, M., Arntz, W. \& Thatje, S. 2007. Sublittoral soft-bottom communities and diversity of Mejillones Bay in northern Chile (Humboldt Current Upwelling System). Helgoland Marine Research, 61: 103-116.

Moraga, J., Valle-Levinson, A. \& Blanco, J.L. 1994. Hidrografía y dinámica de la capa superior del océano en la zona costera del Pacífico Suroriental $\left(30^{\circ} \mathrm{S}\right)$. Investigaciones Pesqueras, 38: 55-73.

Moscoso, V. 2012. Catálogo de crustáceos decápodos y estomatópodos del Perú. Boletín Instituto del Mar del Perú, 27: 8-207.

Mujica, A. 2003. Larvas de crustáceos decápodos de la zona de Aysén. Ciencia y Tecnología del Mar, 26: 109121.

Mujica, A. 2006. Larvas de crustáceos decápodos del archipiélago Juan Fernández (3340'S-7850'W) e Islas Desventuradas $\left(26^{\circ} 20^{\prime} \mathrm{S}-80^{\circ} 05^{\prime} \mathrm{W}\right)$. Ciencia y Tecnología del Mar, 29: 137-152.

Mujica, A. 2007. Dispersión de larvas de crustáceos decápodos en canales y fiordos de la Región de Aysén, Chile. Revista de Biología Marina y Oceanografía, 42: 231-240.

Mujica, A. 2008. Crustáceos decápodos planctónicos de los canales de la XI Región. Ciencia y Tecnología del Mar, 31: 97-108.

Mujica, A., Nava, M.L. \& Vargas, A. 2014. Dispersion of Emerita analoga (Stimpson, 1857) larvae in the northern coast of Chile $\left(25^{\circ}-31.5^{\circ} \mathrm{S}\right)$. Latin American Journal of Aquatic Research, 42: 418-426.

National Oceanic and Atmospheric Administration (NOAA). 2020. ENSO: recent evolution, current status, and predictions. National Weather Service. Climate Prediction Center. [https://www.cpc.ncep. noaa.gov/products/analysis_monitoring/lanina/enso_e volution-status-fcsts-web.pdf]. Reviewed: December $10,2020$.

Retamal, M. 2000. Los decápodos chilenos. World biodiversity database CD-Rom Series. ETIUniversidad de Concepción. Springer, Berlin.

Retamal, M. \& Moyano, H. 2010. Zoogeografía de los crustáceos decápodos chilenos marinos y dulceacuícolas. Latin American Journal of Aquatic Research, 38: 302-328. 
Rivera, J., Guzmán, G. \& Palma, S. 2019. Cross-shelf distribution of decapod larvae in a coastal upwelling zone of northern Chile: some oceanographic implications. Continental Shelf Research, 181: 50-71.

Sánchez, G. \& Aguilar, P. 1975. Notas sobre crustáceos del mar peruano. I. Desarrollo larvario de Lepidopa chilensis Lenz (Decapoda, Anomura: Albunidae). Anales Científicos, Universidad Nacional Agraria La Molina, 12: 1-12.

Received: January 11, 2021; Accepted: June 14, 2021
World Register of Marine Species (WoRMS). WoRMS editorial board. 2020. [http://www.marinespecies.org]. Reviewed: December 10, 2020.

Yannicelli, B., Castro, L.R., Valle-Levinson, A., Atkinson, L. \& Figueroa, D. 2006a. Vertical distribution of decapod larvae in the entrance of an equatorward facing bay of central Chile: implications for transport. Journal of Plankton Research, 28: 19-37.

Yannicelli, B., Castro, L.R., Schneider, W. \& Sobarzo, M. 2006b. Crustacean larvae distribution in the coastal upwelling zone off Central Chile. Marine Ecology Progress Series, 319: 175-189. 